\title{
Involvement of the TRPV1 channel in the modulation of spontaneous locomotor activity, physical performance and physical exercise-induced physiological responses
}

\author{
A.S.R. Hudson, A.C. Kunstetter, W.C. Damasceno and S.P. Wanner \\ Laboratório de Fisiologia do Exercício, Escola de Educação Física, Fisioterapia e Terapia Ocupacional, \\ Universidade Federal de Minas Gerais, Belo Horizonte, MG, Brazil
}

\begin{abstract}
Physical exercise triggers coordinated physiological responses to meet the augmented metabolic demand of contracting muscles. To provide adequate responses, the brain must receive sensory information about the physiological status of peripheral tissues and organs, such as changes in osmolality, temperature and $\mathrm{pH}$. Most of the receptors involved in these afferent pathways express ion channels, including transient receptor potential (TRP) channels, which are usually activated by more than one type of stimulus and are therefore considered polymodal receptors. Among these TRP channels, the TRPV1 channel (transient receptor potential vanilloid type 1 or capsaicin receptor) has well-documented functions in the modulation of pain sensation and thermoregulatory responses. However, the TRPV1 channel is also expressed in non-neural tissues, suggesting that this channel may perform a broad range of functions. In this review, we first present a brief overview of the available tools for studying the physiological roles of the TRPV1 channel. Then, we present the relationship between the TRPV1 channel and spontaneous locomotor activity, physical performance, and modulation of several physiological responses, including water and electrolyte balance, muscle hypertrophy, and metabolic, cardiovascular, gastrointestinal, and inflammatory responses. Altogether, the data presented herein indicate that the TPRV1 channel modulates many physiological functions other than nociception and thermoregulation. In addition, these data open new possibilities for investigating the role of this channel in the acute effects induced by a single bout of physical exercise and in the chronic effects induced by physical training.
\end{abstract}

Key words: Afferent; Capsaicin; Hyperthermia; Metabolism; Physical activity; Thermoregulation

\section{Introduction}

The biomechanical and physiological characteristics of humans suggest that the ability to engage in endurance running was important for obtaining food prior to the adoption of a modern lifestyle (1). Endurance running is defined as running many kilometers over extended time using aerobic metabolism (1). During muscle contraction, several physiological responses occur in the human body, including the mobilization of energy substrates, activation of the sympathoadrenal system, an increase in the heart rate, and the redistribution of blood flow $(2,3)$; collectively, these responses allow adaptation to increased energy expenditure. Because of these physiological responses, physical activity or its subset, physical exercise (i.e., the planned, structured, and repetitive physical activity), can be performed at metabolic rates that are 15 - to 20 -fold higher than the resting metabolic rate (4).
Physical exercise-induced physiological responses are controlled by homeostatic systems, which have principles of operation. Homeostatic systems generally use more than one effector because effector redundancy extends the range for controlling the monitored variables (5). This principle is evidenced by the fact that the lipolysis rate is increased in response to several hormones (e.g., adrenaline, cortisol, growth hormone) enables the compensatory activation of alternative effectors when one of these effectors fails or becomes incapacitated. Moreover, different homeostats (i.e., central integration systems stimulated by different afferent pathways) can regulate the activity of the same effector system. For instance, the regulation of plasma volume and electrolytic balance share the vasopressin effector (5). The neural pathways of homeostatic systems often consist of afferent and efferent components and a central integration

Correspondence: S.P. Wanner: <samuelwanner@eeffto.ufmg.br> 
system; these pathways are not fully described, particularly during exercise.

In the aforementioned context, central integration studies have identified the brain structures and neurotransmitters controlling exercise-induced physiological responses, and substantial progress has been achieved in this area (6-10). However, more research on the participation of afferent pathways in the modulation of physiological responses is still required. A fundamental aspect of homeostatic system function is that blocking the transmission of afferent information to a central integration system will increase the changeability of the monitored variables (5). In agreement with this concept, we demonstrated the fundamental role of arterial baroreceptor signaling in exercise-induced cardiovascular responses (11).

In a different perspective, the role of afferent pathways in exercise fatigue is still debated. Some authors state that the changes occurring at peripheral physiological systems, such as substrate depletion and changes in temperature or metabolite accumulation, act as afferent signalers, which modulate control processes in the brain in a dynamic, nonlinear, and integrative manner (12). Nevertheless, there is not a consensus about this theoretical model that was proposed to explain exercise fatigue (13). Undoubtedly, a deeper understanding of the participation of afferent pathways in exercise-induced physiological responses will help elucidate whether afferents are in fact involved in fatigue and in the modulation of physical performance.

\section{Transient receptor potential (TRP) channels}

Most of the receptors involved in sensorial, afferent pathways express ion channels that sense the physiological status of peripheral tissues, including changes in osmolality, $\mathrm{pH}$, temperature and the presence of other chemical and physical factors. Evidence indicates that the ion channels termed transient receptor potential (TRP) channels are among the receptors responsible for sending sensorial information from the periphery to the central integration system. Six TRP subfamilies have been identified: canonical (TRPC1-7), vanilloid (TRPV1-6), melastatin-like (TRPM1-8), polycystin (TRPP2, TRPP3, and TRPP5), mucolipin (TRPML1-3), and ankyrin-rich (TRPA1) (14).

Recent studies have highlighted the fact that local temperature sensing is a function mediated by the activation of TRP channels (14-16). Eleven TRP channels are highly sensitive to temperature, with three of these channels being activated by cold (TRPM8, TRPA1 and TRPC5) and eight that are activated by heat (TRPV1-4 and TRPM2-5) (14). The thermosensitive TRP channels are activated in response to changes in the local temperature; each channel is sensitive to a specific temperature range. Acting together, these channels sense temperatures ranging from noxious heat to noxious cold (17). Importantly, many TRP channels are activated by stimuli other than temperature and are, therefore, considered polymodal receptors (18).
Among these polymodal TRP channels, the TRPV1 channel (transient receptor potential vanilloid type 1 or capsaicin receptor) has important physiological functions, including the modulation of pain sensation and the physiological responses induced by physical exercise. The TRPV1 channel was isolated and identified by Caterina et al. (19), and as shown in vitro, the channel is sensitive to a temperature range corresponding to noxious heat (activated by temperatures higher than $43^{\circ} \mathrm{C}$ ). Aside from being activated by heat, the TRPV1 channel is also activated by changes in $\mathrm{pH}(20,21)$, by endogenous lipoxygenase products, such as anandamide and oleoylethanolamide $(17,19,21)$, and by exogenous ligands known as vanilloids (e.g., capsaicin and resiniferatoxin; RTX) $(20,21)$. The latter mode of activation was the reason to name these channels vanilloid receptors. Of note, capsaicin is the principal irritating and pungent constituent of various species of red peppers (22). When one of the aforementioned stimuli bind to specific sites of the TRPV1 molecule, this channel opens, causing a transient influx of ions, particularly calcium, and thereby promoting depolarization of the cell membrane (23).

The TRPV1 channel is mainly present in myelinated nerve fibers (type $A \delta$ ) and unmyelinated (type C) nociceptors, which have neural bodies in the dorsal root ganglia, trigeminal ganglia and nodose ganglia (19). TRPV1 expression has been found in the vagus nerve and in brain nuclei that receive vagal afferents, such as the nucleus of the solitary tract $(24,25)$. The TRPV1 channel is also expressed in the hypothalamus (26), skeletal muscles (27) and other peripheral tissues, including the gastrointestinal tract (28), endothelial and smooth muscle cells (29) and arteries (30).

\section{Brief overview of the available tools for studying the physiological roles of the TRPV1 channel}

The scientific literature presents different tools for investigating the physiological functions mediated by the TRPV1 channel. These tools can be divided into three major classes: genetic, nutritional and pharmacological.

The genetic tools have been used to create mice with a deletion of the Trpv1 gene $(31,32)$ and rats that under- or overexpress the TRPV1 channel $(33,34)$. There are several uses for these genetic tools: for instance, knockout mice can be used as a model for human diseases and permit the exploration of the physiological function and significance of specific genes in vivo (35). Nevertheless, the negative results obtained from knockout mice are generally inconclusive because compensatory changes may restore the function of interest, even when the deleted gene is normally responsible for a given function (17). These methods are not applicable to humans. Related studies in humans associate the magnitude of a given response promoted by a nutritional or pharmacological stimulus with the genetic variations that exist within a 
population. For example, the genetic variant TRPV1 Val585lle correlates significantly with the change in abdominal adiposity induced by the prolonged ingestion of capsinoids (36).

The nutritional tools involve the acute or chronic ingestion of capsaicin or non-pungent capsaicin analogs, such as capsiate. This method is employed in experiments with both animals and humans $(37,38)$. However, care should be taken to avoid the direct translation of the outcomes observed in different species because mice, rats and humans have quite different daily food intakes and metabolic rates. Moreover, a researcher should be aware that the gastrointestinal system is one the first physiological systems affected by the ingestion of capsaicin or its analogs.

Lastly, the pharmacological tools involve the administration of TRPV1 agonists and antagonists. Both endogenous (i.e., anandamide or oleoylethanolamide) and exogenous vanilloids (i.e., capsaicin or RTX, a potent agonist naturally found in the plant genus Euphorbia) can be administered as TRPV1 agonists. Furthermore, several TRPV1 antagonists were recently developed by the pharmaceutical industry because of the capacity of such compounds to alleviate pain. Marked technological advancements have been made in this field recently as antagonists that selectively block a specific mode of TRPV1 activation have become available to researchers.

In addition to the administration of antagonists, an alternative method to investigate the physiological function of the TRPV1 channel is to desensitize these channels or the neurons that express them. This desensitization is a chronic phenomenon in which animals stop responding to capsaicin or RTX after the administration of repeated and/or large doses of these drugs (17). Capsaicin is a neurotoxin that destroys nociceptor neurons when administered in high doses. Caterina et al. (19) showed that sensory neurons as well as other TRPV1-expressing cells die after a few hours when treated with capsaicin, and Yamashita et al. (39) observed a reduced number of small diameter sensory fibers in the dorsal root ganglion of capsaicin pre-treated animals.

Having described the available tools for studying the physiological roles of the TRPV1 channel, the following sections will focus on the association between this channel and spontaneous locomotor activity and physical (aerobic) performance, as well as on the TRPV1 involvement in several physiological responses induced by physical exercise.

\section{Spontaneous physical (locomotor) activity}

Spontaneous physical activity is fundamental to the sustainment of life and is positively correlated with physical fitness as the intensity, duration, and frequency of movements increase (40). In rodent experiments, spontaneous locomotor activity is measured in the home cage of the animal or during behavioral assessment tests (Table 1). Thus far, no study has investigated the possible link between spontaneous physical activity and the TRPV1 channel in humans.

The first studies on this topic showed that the deletion of the Trpv1 gene did not change the locomotion of rodents $(21,41)$. However, all of these studies used brief observation periods, sometimes as short as $15 \mathrm{~min}$. By recording spontaneous physical activity throughout the day, Garami et al. (31) observed that knockout mice had higher locomotor activity than that of their wild-type littermates. This finding in knockout mice was confirmed by the use of pharmacological tools; the intraperitoneal administration of RTX (an exogenous TRPV1 agonist) or anandamide (an endogenous TRPV1 agonist) attenuated the stress-induced hyperactivity in mice (31), confirming the reported hypokinetic action of these and other TRPV1 agonists in different tests (42-45). Garami et al. (31) also showed that the locomotor activity response was unaffected by these two TRPV1 agonists in knockout mice, thereby confirming that the anti-hyperkinetic effect of either agonist occurs via an action on TRPV1. In addition, the authors reported that a non-stressful intraperitoneal administration of AMG0347, a highly potent and selective TRPV1 antagonist, increased locomotor activity, an effect that was not observed in knockout mice. The hyperkinesis induced by an acute injection of a TRPV1 antagonist was reproduced recently (46), even when the drug (AMG9810) was injected into mice under stressful conditions. Together, these results support the hypothesis that the TRPV1 channel tonically suppresses general locomotor activity. It should be stated that the augmented locomotor activity caused by TRPV1 antagonists appears to be implicated in the genesis of the hyperthermia side-effect induced by these drugs (see the section on thermoregulation). As evidenced by Alawi et al. (46), no hyperthermic effect was observed after treatment with a TRPV1 antagonist when mice were anesthetized and thus unable to move.

Quite unexpectedly, older knockout mice showed an opposite behavior, that is, decreased spontaneous locomotor activity compared with that of their age-matched wildtype littermates, which indicates that the TRPV1-mediated regulation of locomotor activity is age-dependent. Moreover, the decreased physical activity may help explain the exaggerated increase in the body mass of the knockout mice as they age (32) (Figure 1).

\section{Physical (aerobic) performance}

Because the TRPV1 channel is highly expressed in nerve endings and in peripheral tissues, this channel is most likely involved in the regulation of several physiological functions, including thermoregulatory (47), cardiovascular $(30,48)$ and metabolic functions $(38)$. The TRPV1 channel also plays a role in systemic inflammation (49) and protects 
Table 1. Association between the transient receptor potential vanilloid type 1 (TRPV1) channel and spontaneous locomotor activity.

\begin{tabular}{|c|c|c|c|}
\hline Study & $\begin{array}{l}\text { Experimental } \\
\text { approach }\end{array}$ & Experimental setup & Outcome \\
\hline $\begin{array}{l}\text { Caterina et al., } \\
2000[21]\end{array}$ & Genetic & $\begin{array}{l}\text { The manuscript does not describe how locomotion } \\
\text { was evaluated. }\end{array}$ & $\begin{array}{l}\text { Trp } v 1^{-/-} \text {mice expressed unaltered locomotion } \\
\text { compared with their wild-type littermates. }\end{array}$ \\
\hline $\begin{array}{l}\text { Davis et al., } \\
2000[41]\end{array}$ & Genetic & $\begin{array}{l}\text { Six- to 9-week-old male } \operatorname{Trpv} 1^{-/-} \text {and } \operatorname{Trpv} 1^{+/+} \text {mice } \\
\text { were subjected to a } 30 \text {-min spontaneous locomotor } \\
\text { activity test and a 10-min hole board test of exploratory activity. }\end{array}$ & $\begin{array}{l}\text { Trpv1 } 1^{-1-} \text { mice did not exhibit changes in either } \\
\text { spontaneous locomotor activity or exploratory } \\
\text { activity compared with their wild-type littermates. }\end{array}$ \\
\hline $\begin{array}{l}\text { Garami et al., } \\
2011[31]\end{array}$ & Genetic & $\begin{array}{l}\text { Seventeen-week-old C57BL/6x129 Trpv1 }{ }^{+/+} \text {and Trpv1 } 1^{-/-} \\
\text {mice of both sexes were measured for spontaneous } \\
\text { locomotor activity with two different experimental setups } \\
\text { (telemetric thermometry and a thermogradient setup). }\end{array}$ & $\begin{array}{l}\text { Trpv1/- mice expressed a higher locomotor } \\
\text { activity, especially during the light phase. }\end{array}$ \\
\hline $\begin{array}{l}\text { Wanner et al., } \\
2011[32]\end{array}$ & Genetic & $\begin{array}{l}\text { Forty-four-week-old male C57BL/6x129 } \operatorname{Trpv} 1^{+/+} \text {and } \\
\operatorname{Trpv} 1^{-/-} \text {mice were measured for spontaneous locomotor } \\
\text { activity by radiotelemetry over } 48 \mathrm{~h} \text { in their home cages. }\end{array}$ & $\begin{array}{l}\operatorname{Trpv1}^{-1-} \text { mice at more advanced ages showed } \\
\text { decreased spontaneous locomotor activity compared } \\
\text { to wild-type littermates. This difference was observed } \\
\text { both in the light and dark phases of the day. }\end{array}$ \\
\hline $\begin{array}{c}\text { Alawi et al., } \\
2015 \text { [46] }\end{array}$ & Genetic & $\begin{array}{l}\text { Male, age-matched (8-15 weeks of age) C57BL6/129SvJ } \\
\text { WT and Trpv1 } 1^{-/-} \text {mice were measured for spontaneous } \\
\text { locomotor activity by radiotelemetry over } 24 \mathrm{~h} \text { in their } \\
\text { home cages. }\end{array}$ & $\begin{array}{l}\operatorname{Trpv} 1^{-1-} \text { mice exhibited higher locomotor activity } \\
\text { than } \operatorname{Trpv} 1^{+/+} \text {mice during the light phase but not } \\
\text { during the dark phase. }\end{array}$ \\
\hline $\begin{array}{l}\text { Di Marzo et al., } \\
2001[42]\end{array}$ & Pharmacological & $\begin{array}{l}\text { Male Wistar rats (older than } 10 \text { weeks) received } \\
\text { intraperitoneal injections of capsaicin, livanil, linvanil and } \\
\text { anandamide in doses ranging from } 0.1 \text { to } 10 \mathrm{mg} / \mathrm{kg} \text {. The } \\
\text { rats were placed in the middle of an open field and were } \\
\text { recorded for } 5 \mathrm{~min} \text {. Ambulation (number of squares } \\
\text { crossed), time spent in inactivity, and frequency of } \\
\text { stereotypic behaviors (rearing, self-grooming and shaking) } \\
\text { were measured. }\end{array}$ & $\begin{array}{l}\text { All of these TRPV1 agonists inhibited ambulation } \\
\text { and stereotypic behavior and increased inactivity } \\
\text { in the open field test in a dose-dependent manner. } \\
\text { The following rank of potency was observed: } \\
\text { livanil }>\text { capsaicin }>\text { linvanil }>\text { anandamide. }\end{array}$ \\
\hline $\begin{array}{l}\text { Proulx et al., } \\
2005 \text { [43] }\end{array}$ & Pharmacological & $\begin{array}{l}\text { Male Long-Evans rats weighing } 250-300 \mathrm{~g} \text { received } \\
\text { intraperitoneal injections of capsaicin ( } 1 \mathrm{mg} / \mathrm{kg} \text { ), } \\
\text { oleoylethanolamide (an endogenous lipid that activates } \\
\text { TRPV1 channels; } 20 \mathrm{mg} / \mathrm{kg} \text { ) or the respective vehicles } 10 \\
\text { min before testing. The rats were placed in the middle of } \\
\text { the open field and were videotaped for } 10 \mathrm{~min} \text { (only the last } \\
5 \mathrm{~min} \text { were analyzed). Ambulation (number of squares } \\
\text { crossed), time spent in inactivity, and spontaneous activity } \\
\text { (number of rearing or grooming events) were measured. }\end{array}$ & $\begin{array}{l}\text { The rats treated with oleoylethanolamide were } \\
\text { significantly more inactive and showed significant } \\
\text { decreases in ambulation and spontaneous activity } \\
\text { compared to the vehicle-treated rats. Similar to } \\
\text { oleoylethanolamide, capsaicin significantly } \\
\text { inhibited spontaneous activity compared to the } \\
\text { respective vehicle. However, capsaicin did not } \\
\text { change ambulation and time spent in inactivity. }\end{array}$ \\
\hline $\begin{array}{l}\text { Garami et al., } \\
2011[31]\end{array}$ & Pharmacological & $\begin{array}{l}\text { Seventeen-week-old C57BL/6x129 } \operatorname{Trpv} 1^{+/+} \text {and } \operatorname{Trpv} 1^{-/-} \\
\text {mice and } 17 \text { week-old C57BL/6 } \operatorname{Trpv} 1^{+/+} \text {mice of both } \\
\text { sexes received intraperitoneal injections of resiniferatoxin } \\
(200 \mathrm{ng} / \mathrm{kg}) \text {, anandamide }(15 \mathrm{mg} / \mathrm{kg}), \text { AMG0347 }(50 \mu \mathrm{g} / \mathrm{kg}) \\
\text { or their respective vehicles. Their spontaneous locomotor } \\
\text { activity was measured with a telemetric thermometry setup. }\end{array}$ & $\begin{array}{l}\text { The intraperitoneal administration of the TRPV1 } \\
\text { agonists resiniferatoxin and anandamide } \\
\text { decreased spontaneous locomotor activity in } \\
\text { C57BL/6x129 Trpv1 } 1^{+/+} \text {and in C57BL/6 Trpv1 } 1^{+/+} \\
\text {mice but not in C57BL/6x129 Trpv1 } 1^{-/-} \text {mice. In } \\
\text { contrast, the intraperitoneal administration of the } \\
\text { highly selective TRPV1 antagonist AMG0347 } \\
\text { increased spontaneous locomotor activity in } \\
\text { C57BL/6x129 Trpv1 } 1^{+/+} \text {and in C57BL/6 Trpv1 } 1^{+/+} \\
\text {mice but not in C57BL/6x129 Trpv1 } 1^{-/-} \text {mice. }\end{array}$ \\
\hline $\begin{array}{c}\text { Alawi et al., } \\
2015[46]\end{array}$ & Pharmacological & $\begin{array}{l}\text { Male, age-matched (8-15 weeks of age) C57BL6/129SvJ } \\
\text { wild-type and Trpv1/- mice received intraperitoneal } \\
\text { injections of the TRPV1 antagonist AMG9810 (50 mg/kg) } \\
\text { or vehicle. Their spontaneous locomotor activity was } \\
\text { recorded with radiotelemetry over } 6 \mathrm{~h} \text {. The experiments } \\
\text { were conducted both in awake and anesthetized mice. }\end{array}$ & $\begin{array}{c}\text { The intraperitoneal injection of a TRPV1 } \\
\text { antagonist promoted a sustained increase of } \\
\text { spontaneous activity in wild-type mice when } \\
\text { compared to the effects of vehicle injection. The } \\
\text { TRPV1 antagonist failed to elicit hyperkinesis in } \\
\text { the Trpv1 } 1^{-/-} \text {mice. }\end{array}$ \\
\hline
\end{tabular}

$\operatorname{Trpv1}^{-I^{-}}$: mice with a homozygous targeted null mutation in the Trpv1 gene; $\operatorname{Trpv1} 1^{+{ }^{+}}:$wild-type mice without a homozygous targeted null mutation of the Trpv1 gene. 


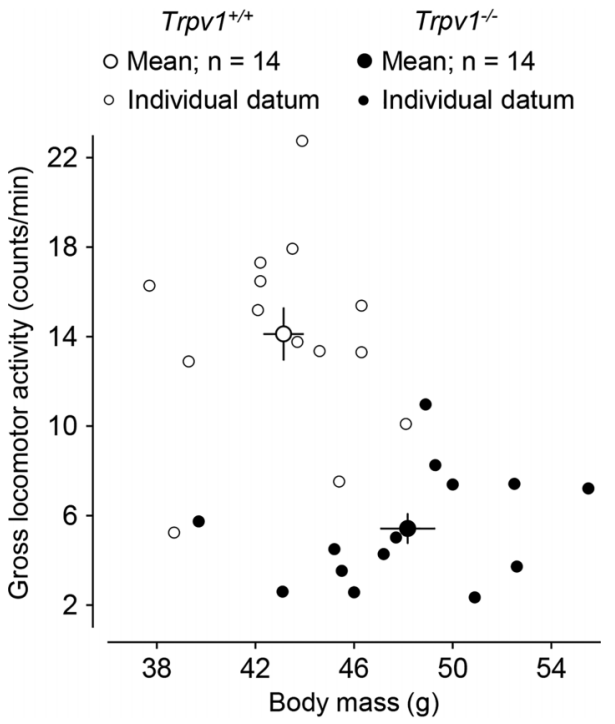

Figure 1. Transient receptor potential vanilloid type 1 (TRPV1) channel modulates spontaneous locomotor activity. The figure shows that aged Trpv1-knockout mice have a higher body mass and lower spontaneous locomotor activity than their genetically unaltered littermates. The figure was modified from Wanner et al. (32).

the gastrointestinal tract against inflammatory or functional gastrointestinal diseases (28). Together, these TRPV1mediated functions (which are discussed in detail in the subsequent sections) may affect the physiological response to exercise and, therefore, influence fatigue and physical performance.

The role of the TRPV1 channel in the modulation of physical performance is still unclear; reports indicate that TRPV1 activation improves or does not change aerobic performance (Table 2). Luo et al. (34) observed an increase in the exercise performance of rats subjected to treadmill running after a 3-month treatment with dietary capsaicin. Similarly, Kim et al. (50) and Oh et al. (51) showed that a single oral administration of capsaicin increased the swimming endurance in mice. In agreement with the latter findings, TRPV1-desensitized rats displayed impaired performance during treadmill running. Dousset et al. (52) showed a shorter time to fatigue in adult rats that had received neonatal treatments of capsaicin compared with rats that received neonatal treatments of vehicle. However, Trudeau and Milot (53) observed no differences in swimming performance between TRPV1-desensitized and control rats. As in the study of Dousset et al. (52), the rats were desensitized neonatally and tested as adults. The different outcomes observed in these studies may result from type of exercise (treadmill running vs swimming), the animal species (rats vs mice) and the experimental approach for assessing TRPV1 function (pharmacological vs nutritional tools). Recently, more selective pharmacological tools (e.g., new TRPV1 antagonists) have been developed, allowing a more precise investigation of the physiological functions mediated by the TRPV1 channel. Therefore, future studies should be performed to enhance our understanding of why the activation of these channels produces different modulatory effects on spontaneous physical activity (decrement) and physical exercise performance (improvement). Interestingly, no study has addressed the relationship between TRPV1 and physical performance in humans.

\section{Thermoregulation}

Although the molecular structure of the TRPV1 channel was identified in 1997, the effects of capsaicin (i.e., an exogenous vanilloid) on body temperature have been known for several decades (54). The acute systemic administration of an exogenous vanilloid (either capsaicin or RTX) decreases the core body temperature $(54,55)$ by increasing the cutaneous heat loss $(54,56,57)$ and by promoting behaviors aimed at decreasing body heat conservation, such as the selection of an environment with lower temperature (55). After this initial hypothermic effect, the energy expenditure subsequently increases, which is likely due to a neuroendocrine counter-regulatory response involving the activation of the sympathetic nervous system and the hypothalamic-pituitary-adrenal axis (58). The physiological effects induced by capsaicin and RTX are not observed in mice with a genetic deletion of the TRPV1 channel (Trpv1-knockout mice), indicating that these channels mediate the physiological responses elicited by both exogenous vanilloids (21).

The studies on the role of the TRPV1 channel in the modulation of physiological responses have drawn the attention of many researchers due to the role of this channel in the modulation of pain $(21,59-61)$. For example, TRPV1 activation by the acute administration of exogenous agonists caused behaviors associated with pain and inflammation at the injection site (21). Thus, TRPV1 antagonists were and are being developed as powerful analgesics $(59,60)$; clinical trials indicated that the pharmacological blockade of TRPV1 channels produces analgesia after the extraction of a molar tooth, which represents an experimental model for the acute pain caused by surgery in humans. However, all of the subjects that participated in these clinical trials showed long-lasting hyperthermia, with one of these participants showing core temperature values higher than $40^{\circ} \mathrm{C}(62)$. This hyperthermia side effect was reproduced in several animal species (including mice; Figure 2) and results from decreased cutaneous heat loss and increased thermogenesis $(46,47,63)$, suggesting that the TRPV1 channel is tonically active in vivo to regulate core temperature. This tonic activation inhibits heat production/conservation and activates heat loss pathways, thus contributing to the maintenance of core temperature within the normal, resting range $(17,47)$. Therefore, the administration of an antagonist removes the tonic TRPV1 
Table 2. Association between the transient receptor potential vanilloid type 1 (TRPV1) channel and physical (aerobic) performance.

\begin{tabular}{|c|c|c|c|c|}
\hline Study & $\begin{array}{l}\text { Experimental } \\
\text { approach }\end{array}$ & Experimental setup & $\begin{array}{l}\mathrm{T}_{\mathrm{AMB}} \\
\left({ }^{\circ} \mathrm{C}\right)\end{array}$ & Outcome \\
\hline $\begin{array}{l}\text { Kim et al., } \\
1997 \text { [50] }\end{array}$ & Nutritional & $\begin{array}{c}\text { Six-week-old male mice were administered } \\
\text { capsaicin ( } 3-15 \mathrm{mg} / \mathrm{kg} \text { body mass) or vehicle } \\
\text { by gavage at different time points (30,60, } 120 \\
\text { and } 180 \mathrm{~min} \text { ) before a swimming exercise. } \\
\text { Swimming was performed in a circular tank } \\
\text { filled with water (water depth of } 38 \mathrm{~cm}) \text {. The } \\
\text { mice were considered fatigued when they failed } \\
\text { to rise to the surface of the water to breathe } \\
\text { within a } 7-\mathrm{s} \text { period. }\end{array}$ & $34^{\circ} \mathrm{C}$ & $\begin{array}{l}\text { When administered } 120 \text { min prior to } \\
\text { the exercise, capsaicin ( } 6 \mathrm{mg} / \mathrm{kg} \text { ) } \\
\text { increased the swimming time until } \\
\text { exhaustion. No effects on } \\
\text { performance were observed when } \\
\text { the same dose was administered } 30 \text {, } \\
60 \text { or } 180 \text { min prior to exercise. A } \\
\text { dose-dependent response was } \\
\text { observed when capsaicin was } \\
\text { administered at } 120 \text { min prior to } \\
\text { exercise. Swimming exercise } \\
\text { capacity was maximized at a dosage } \\
\text { of } 10 \mathrm{mg} / \mathrm{kg} \text {, with no further increase } \\
\text { observed at } 15 \mathrm{mg} / \mathrm{kg} \text {. }\end{array}$ \\
\hline $\begin{array}{l}\text { Oh et al., } \\
2003 \text { [51] }\end{array}$ & Nutritional & $\begin{array}{l}\text { Four-week-old male Sprague-Dawley rats were } \\
\text { given either vehicle or capsaicin by gavage at } \\
\text { three different doses (6,10 or } 15 \mathrm{mg} / \mathrm{kg} \text { body } \\
\text { mass) } 2 \mathrm{~h} \text { before a swimming exercise. The } \\
\text { mice were considered fatigued when they failed } \\
\text { to rise to the surface of the water to breathe } \\
\text { within a } 7 \text {-s period. }\end{array}$ & $36 \pm 2^{\circ} \mathrm{C}$ & $\begin{array}{l}\text { Only the highest dose }(15 \mathrm{mg} / \mathrm{kg}) \text { of } \\
\text { capsaicin significantly increased } \\
\text { endurance performance time } \\
\text { compared with vehicle. }\end{array}$ \\
\hline $\begin{array}{l}\text { Luo et al., } \\
2012 \text { [34] }\end{array}$ & Nutritional & $\begin{array}{l}\text { Six- to 8-week-old male C57BL/6J wild-type } \\
\text { and Trpv1 }{ }^{-/-} \text {mice were fed a regular diet or a } \\
\text { diet supplemented with } 0.01 \% \text { capsaicin. Then, } \\
\text { these mice were subjected to an exercise on a } \\
\text { treadmill that consisted of } 60 \text { min of running at } \\
10 \mathrm{~m} / \mathrm{min} \text {, followed by } 1 \mathrm{~m} / \mathrm{min} \text { increases in the } \\
\text { treadmill speed at } 15-\mathrm{min} \text { intervals. The mice } \\
\text { were considered exhausted when they were } \\
\text { unable to avoid repeated electrical shocks. }\end{array}$ & $\begin{array}{c}\text { Not } \\
\text { informed }\end{array}$ & $\begin{array}{l}\text { Dietary capsaicin }(3,6,9 \text { and } 12 \\
\text { months of treatment) increased the } \\
\text { distance traveled by wild-type mice } \\
\text { during the exercise endurance tests } \\
\text { but did not change the distance } \\
\text { traveled by } \operatorname{Trpv} 1^{-/-} \text {mice. }\end{array}$ \\
\hline $\begin{array}{l}\text { Trudeau and } \\
\text { Millot, } 1996 \\
\text { [53] }\end{array}$ & Pharmacological & $\begin{array}{l}\text { Male Sprague-Dawley rats received a } \\
\text { subcutaneous injection of either } 50 \mathrm{mg} / \mathrm{kg} \\
\text { capsaicin (desensitized group) or vehicle } \\
\text { (control group) during their fourth to fifth day of } \\
\text { life. Three months later, the rats were subjected } \\
\text { to a swimming exercise until exhaustion. Each } \\
\text { rat had a weight ( } 3 \% \text { of body mass) attached to } \\
\text { its tail throughout the swim-to-exhaustion. The } \\
\text { criterion for exhaustion was the animal's } \\
\text { inability to reach the surface for a period of } 10 \mathrm{~s} \text {. }\end{array}$ & $36^{\circ} \mathrm{C}$ & $\begin{array}{l}\text { No differences in swimming } \\
\text { performance were observed between } \\
\text { the TRPV1-desensitized and the } \\
\text { controls rats. }\end{array}$ \\
\hline $\begin{array}{l}\text { Dousset et al., } \\
2004 \text { [52] }\end{array}$ & Pharmacological & $\begin{array}{l}\text { Female Sprague-Dawley rats received a } \\
\text { subcutaneous injection of either } 50 \mathrm{mg} / \mathrm{kg} \text { capsaicin } \\
\text { (desensitized group) or vehicle (sham group) during } \\
\text { their second day of life. These two groups were } \\
\text { compared with a control, untreated group. Four } \\
\text { months later, the running performance of the rats } \\
\text { was evaluated on a treadmill with a speed of } 16 \mathrm{~m} / \\
\text { min and a slope of }-13 \% \text {. Exhaustion was reached } \\
\text { when rats lost their righting reflex and could no } \\
\text { longer run on the treadmill. }\end{array}$ & $\begin{array}{c}\text { Not } \\
\text { informed }\end{array}$ & $\begin{array}{l}\text { The desensitized group exhibited a } \\
\text { reduced maximal capacity for } \\
\text { exercise, i.e., a shorter time to } \\
\text { exhaustion than the sham and } \\
\text { untreated groups. }\end{array}$ \\
\hline
\end{tabular}

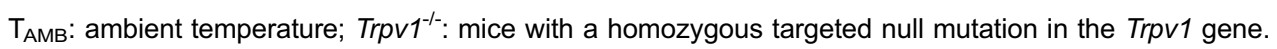




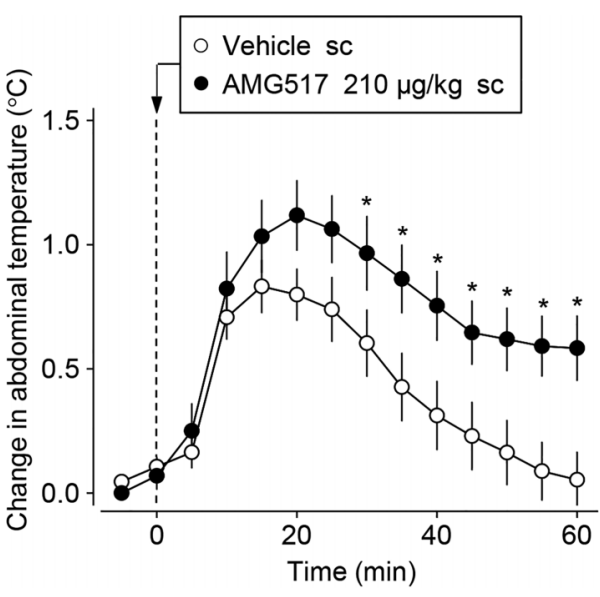

Figure 2. Systemic administration of a TRPV1 antagonist induces hyperthermia. The figure shows that subcutaneous injection of AMG517 $(210 \mu \mathrm{g} / \mathrm{kg}, s c)$ increases the abdominal temperature of young mice maintained at $28^{\circ} \mathrm{C}$. ${ }^{*}$ Significant difference $(P<0.05)$ compared to vehicle. TRPV1: transient receptor potential vanilloid type 1. The figure was modified from Wanner et al., 2012 (78).

action on the thermoregulatory effectors, thereby causing hyperthermia (47).

To date, these side effects have limited the use of TRPV1 antagonists for the treatment of pain. It is likely that the unwanted hyperthermic effect depends on the different factors associated with channel activation, i.e., the potency of an antagonist in causing hyperthermia is related to the potency of the drug in blocking a certain mode (or modes) of TRPV1 activation (60). Evidence indicates that the administration of TRPV1 antagonists that do not block the proton-mode of activation but do block the activation by capsaicin and high temperature causes analgesia without triggering the unwanted hyperthermic effect $(59,60)$.

The hyperthermia mediated by the administration of antagonists that block all of the modes of TRPV1 channel activation, such as AMG9810 and AMG0347, is an ontarget effect because hyperthermia is not observed in Trpv1-knockout mice treated with these antagonists $(31,46,47)$. A recent study provided evidence that TRPV1 controls resting thermoregulation by acting upstream in the activation of the sympathetic nervous system (46). Acute removal of the TRPV1 regulatory activity via the administration of an antagonist results in increased sympathetic outflow, characterized by higher levels of noradrenaline in the brown adipose tissue and the circulation (46), and this increased sympathetic outflow most likely favors the manifestation of hyperthermia. Interestingly, Alawi et al. (46) reported that deletion of the Trpv1 gene results in a compensatory suppression of sympathetic activity and associated thermoregulatory pathways, which may explain the normal basal temperature of the knockout mice.
The involvement of the TRPV1 channel in thermoregulation is also supported by studies that employed techniques aimed at desensitizing this channel. As a consequence of the TRPV1 desensitization caused by pretreatment with capsaicin, rats showed exaggerated increases in core temperature during exposure to a hot environment $(54,57)$. This inability to regulate the core temperature during heat exposure is associated with altered activity of the autonomic and behavioral thermoeffectors $(4,54,57)$. Obál et al. (64) showed that desensitized animals exhibit lower cutaneous vasodilation in response to body heat storage, a failure to increase the grooming behavior during heat exposure, and a preference for a warm rather than a cold environment, even in situations of increased core temperature. In addition, JancsóGábor (54) showed that the desensitized animals salivate less and, therefore, experience less evaporative heat loss when exposed to heat. However, Dib et al. (65) observed no differences in the cold-air requirements of desensitized and control animals during exposure to a hot environment. Taken together, these findings suggest that the TRPV1 channel modulates the recruitment of autonomic and some behavioral thermoeffectors in heat-exposed animals. Future studies should investigate the TRPV1-mediated recruitment of autonomic and behavioral thermoeffectors during physical exercise, a condition in which heat is markedly produced by metabolism and not necessarily gained from the environment.

\section{Metabolism}

TRPV1 is involved in metabolism $(14,58)$. Evidence indicates that $\operatorname{Trpv} 1-\mathrm{knockout}$ mice become obese as they age $(31,32)$, although this result is not a universal observation (66). Haramizu et al. (37) reported that the oral treatment of mice for two weeks with capsiate promoted an improvement in energy metabolism and an inhibition of body fat accumulation, which are quite similar to the effects induced by regular swimming. In fact, the ingestion of TRPV1 agonists increase the lipolysis rate in exercising humans $(38,67)$ without changing the plasma concentrations of epinephrine or norepinephrine (38). Along similar lines, mice treated with capsaicin exhibited higher plasma glucose and free fatty acid concentrations at rest (50) and after swimming (51). Nevertheless, measurements of the plasma catecholamine concentrations in exercising animals do not agree with the results of the previous study in humans. The plasma epinephrine and norepinephrine levels were higher in the control than in the TRPV1-desensitized rats that were subjected to exhausting exercise (53) and were higher in mice orally treated with capsaicin than in mice treated with placebo at the end of an exhausting swimming exercise (51). In summary, these results suggest that TRPV1 activation leads to increases in energy expenditure and lipolysis rate in exercising humans and rodents and thereby to sympathoadrenal excitation, at least in rodents. 


\section{Cardiovascular system}

The cardiovascular system is another important physiological system for exercise performance that may be regulated by the TRPV1 channel. Recent studies aimed to investigate the relationship between the capsaicin receptor and cardiovascular responses $(29,30,47)$. Steiner et al. (47) and Sun et al. (30) observed that systemic activation of the TRPV1 channel by the administration of capsaicin reduces the mean arterial pressure, the heart rate and renal sympathetic activation. When the animals were previously treated with a potent TRPV1 antagonist, the cardiovascular effects promoted by capsaicin were prevented, except for a brief reduction in the heart rate (30). Furthermore, the TRPV1 channel is present in afferent elements of the baroreflex pathway; these channels are expressed in aortic baroreceptors, nodose ganglion neurons and the nucleus of the solitary tract (30). Additionally, the latter investigators demonstrated that systemic TRPV1 desensitization impairs the reflex control of blood pressure.

The TRPV1 channel is also involved in the exercise pressor reflex. Smith et al. (48) reported that TRPV1 blockade attenuates the increase in blood pressure during isometric contractions. Recently, TRPV1 expression was found in the vascular endothelium and smooth muscles (29). The activation of TRPV1 channels located in the vascular endothelium produces vasodilation by increasing the phosphorylation of endothelial nitric oxide synthase $(68,69)$. Moreover, dietary capsaicin enhances TRPV1 expression in endothelial cells, and this response is associated with an increase in endothelium-dependent vasodilation (68). The activation of the TRPV1 channels also induces vasodilation via increased release of the calcitonin gene-related peptide at the nerve terminals of capsaicin-sensitive neurons that innervate peripheral arteries (70). This vasodilation seems to mediate the decrease in blood pressure observed after the administration of TRPV1 agonists. Therefore, it is likely that TRPV1 activation changes the reflex regulation of blood pressure and the vasomotor tone, thereby changing the cardiovascular response during physical efforts. In addition, we assume that physical training may modulate the expression of these channels, as indicated in a study conducted with animals that were experimentally subjected to heart failure; aerobic training partially reversed the reduced TRPV1 expression in the dorsal root ganglia and partially restored the response of group IV afferents to an intra-arterial injection of capsaicin (71).

\section{Gastrointestinal system}

The TRPV1 channel may also modulate aerobic performance and physiological responses to exercise by affecting gastrointestinal function. Gastrointestinal symptoms have been observed in $30-50 \%$ of athletes competing in prolonged events, such as marathon runners and cyclists (72), and have been observed in up to $93 \%$ of participants in a long-distance triathlon (73). Overall, although these symptoms are not severe, they may compromise sport performance by reducing exercise intensity or even ceasing the exertion during a competition (73). In fact, physical exercise under conditions of environmental heat stress leads to increases in intestinal permeability and in the bacterial content in the blood and liver of mice (74). Augmented intestinal permeability may be one of the causes of the surge in gastrointestinal symptoms.

Although capsaicin receptors are mainly located in neurons, these receptors were identified in non-neuronal cells of the digestive tract of various animal species, including humans. Cells with immunoreactivity to TRPV1 were identified in the epithelial tissue of the esophagus and stomach and in the small bowel mucosa $(75,76)$. The TRPV1 channel is likely important in tissue protection and in the restoration of epithelial tissue because changes in TRPV1 expression are observed in response to several inflammatory or functional gastrointestinal diseases (28). The capsaicin receptor protects the gastrointestinal barrier function, thus preventing the increase in permeability $(17,62)$. These protective effects result from the modulation of the host immune response (77) and the regulation of local blood flow (78) and the cellular ionic medium (78). The latter mechanism is supported by observations showing that changes in ion flux influence the binding of tight junctions (79). It is therefore likely that TRPV1 channels help to maintain the integrity of the gastrointestinal barrier during exercise.

\section{Inflammation}

The TRPV1 channel is critically involved in the systemic responses such as augmented energy expenditure and water retention that favor inflammation (58). TRPV1 is stimulated by a whole range of pro-inflammatory factors (58), and the injection of TRPV1 agonists (either capsaicin or RTX) induces pain at the injection site (21). In addition, there is evidence that gastrointestinal inflammation causes hyperalgesia at least in part by the upregulation and sensitization of TRPV1 (28), and that TRPV1 desensitization changes the release of TNF- $\alpha$ during sepsis (80). However, the induction of a pro-inflammatory response after the activation of the TRPV1 channel is not a universal finding (49). For instance, the administration of a TRPV1 antagonist (capsazepine) increased mortality in rats treated with a shock-inducing dose of lipopolysaccharides (81); of note, the administration of high doses of lipopolysaccharides represents an experimental model that produces an exaggerated systemic inflammatory response syndrome that usually causes animal death. Thus, at least in rodents undergoing aseptic systemic inflammation, the TRPV1 channel appears to play an anti-inflammatory (regulatory) role. According to Holzer (28), the observations that TRPV1 stimulation either reduces or exaggerates tissue inflammation may reflect stimulus- and tissue-dependent differences in the process of neurogenic inflammation. It is relevant to 
point out that the role of TRPV1 in inflammation may be influenced by aging because the effect of a TRPV1 antagonist (AMG517) on the inflammatory response caused by a shock-inducing dose of lipopolysaccharides in aged mice was the opposite to that observed in young mice (77).

Inflammatory responses may be indirectly linked to physical performance. It has been proposed that part of the increase in core temperature observed during exercise is caused by the augmented production of pro-inflammatory cytokines that results from the increased core temperature. This mechanism could generate a cyclical phenomenon, that is, increases in core temperature augment bacterial translocation through the gut wall, which in turn promotes systemic inflammation and ultimately further increases the core temperature $(73,82)$. Jeukendrup et al. (73) and Bradford et al. (82), respectively, showed that in humans, the plasma concentrations of IL- 6 and TNF- $\alpha$ increased during prolonged exercise. This increase in circulating cytokines may enhance exercise hyperthermia through the stimulation of the synthesis and release of prostaglandin $E_{2}$ $\left(\mathrm{PGE}_{2}\right)$ by the brain (83). In fact, the administration of a $\mathrm{PGE}_{2}$ synthesis inhibitor mitigated exercise-induced hyperthermia in humans (82). Similarly, heat strain was increased during endurance exercise in the heat that was conducted $30 \mathrm{~min}$ after a muscle-damaging eccentric exercise, which increased the circulating levels of IL-6 (84). Thus, it is likely that the TRPV1 channel changes the inflammatory status during exercise and changes thermoregulatory responses, partially by modulating the release of pro-inflammatory cytokines.

\section{Water and electrolyte balance}

Aside from the aforementioned physiological functions, the TRPV1 channel is also involved in the regulation of plasma volume and osmotic balance. Increases in the core temperature induce thermoregulatory responses that promote water loss, generating internal hyperosmolar conditions (58). In this context, the TRPV1 channels in the hypothalamus assist in the regulation of plasma volume by promoting water retention (85). This activation of hypothalamic capsaicin receptors may become important during physical exertion, when the core temperature is usually increased and water is lost to facilitate evaporative heat loss from the body.

\section{Muscular hypertrophy and mitochondrial biogenesis}

TRPV1 channels may also participate in some chronic adaptations induced by regular physical exercise or training programs, including muscular hypertrophy and mitochondrial biogenesis. The TRPV1 channels are expressed in human skeletal muscle (86). As suggested by studies conducted using mice and rats, these channels are expressed in the sarcoplasmic reticulum membrane but not in the sarcolemma $(27,87)$. The activation of the capsaicin receptor promotes the release of calcium from the sarcoplasmic reticulum, which in turn stimulates the mammalian target rapamycin, a molecular mediator that promotes muscle hypertrophy. These findings suggest that the effects induced by capsaicin administration are comparable to the effects induced by mechanical overload (88). Collectively, these
Physical (aerobic) performance

TRPV1 activation improves or does not change physical performance.

Spontaneous locomotor activity

The TRPV1 channel tonically suppresses spontaneous locomotor activity.

\section{Thermoregulation}

TRPV1 channels tonically inhibit cold-defense responses by modulating the recruitment of autonomic and some behavioral thermoeffectors. However, whether TRPV1 modulates

thermoregulation during exercise is still unknown.

\begin{tabular}{|l|}
\hline Metabolism \\
TRPV1 activation leads to increased energy \\
expenditure and, therefore, affects substrate \\
mobilization and metabolic rate during exercise. \\
\hline Cardiovascular system \\
TRPV1 is present in afferent elements of the \\
baroreflex and controls vasomotor tone. The \\
TRPV1 channel is also involved in the exercise \\
pressor reflex, thereby modulating the \\
cardiovascular response during physical efforts. \\
\hline
\end{tabular}

Gastrointestinal system

TRPV1 helps to maintain the integrity of the gastrointestinal barrier in response to several inflammatory or functional gastrointestinal diseases. However, whether TRPV1 protects the gastrointestinal barrier during exercise is still unknown

\section{Inflammation}

TRPV1 either reduces or exaggerates tissue

inflammation depending on the stimulus and the tissue studied. Whether TRPV1 plays an inflammatory role during exercise and therefore indirectly affects thermoregulation is still unknown

Water and electrolytic balance

TRPV1 regulates plasma volume and osmotic balance. However, whether TRPV1 controls water and electrolytic balance during exercise is still unknown.

Muscle

TRPV1 is involved in molecular pathways associated with muscle hypertrophy. In addition, chronic TRPV1 activation promotes

mitochondrial biogenesis, thereby increasing the oxidative capacity of muscle fibers.
Figure 3. Overview of the physiological functions exerted by transient receptor potential vanilloid type 1 (TRPV1) channels. The green boxes indicate responses that are mediated by TRPV1 channels during physical activity or exercise, whereas the red boxes indicate TRPV1-mediated physiological responses that have not been investigated under such conditions. 
results indicate the potential of TRPV1 agonists in the development of ergogenic strategies and for reversing clinical conditions, such as muscle atrophy.

In addition to muscular hypertrophy, mitochondrial biogenesis is also likely altered by the chronic administration of capsaicin. The in vitro administration of capsaicin promoted the expression of peroxisome proliferator-activated receptor gamma co-activator-1 $\alpha$ (PGC- $1 \alpha)$ in $\mathrm{C} 2 \mathrm{C} 12$ myotubes (34). Moreover, PGC-1 $\alpha$ was upregulated in vivo in skeletal muscle by dietary capsaicin-induced TRPV1 activation or genetic overexpression of TRPV1 in mice. In addition, TRPV1 activation increased the expression of genes involved in fatty acid oxidation and mitochondrial respiration, promoted mitochondrial biogenesis and increased the number of oxidative fibers. These beneficial adaptations promoted by dietary capsaicin prevented high-fat dietinduced metabolic disorders (34).

\section{Final remarks}

In addition to nociception and thermoregulatory responses, new functions of the TRPV1 channel have been revealed by recent studies; these functions are associated with the modulation of spontaneous physical activity and the regulation of muscle homeostasis, metabolism, osmolality

\section{References}

1. Bramble DM, Lieberman DE. Endurance running and the evolution of Homo. Nature 2004; 432: 345-352, doi: 10.1038/ nature03052.

2. Vatner SF, Pagani M. Cardiovascular adjustments to exercise: hemodynamics and mechanisms. Prog Cardiovasc Dis 1976; 19: 91-108, doi: 10.1016/0033-0620(76)90018-9.

3. Galbo $\mathrm{H}$. The hormonal response to exercise. Diabetes Metab Rev 1986; 1: 385-408, doi: 10.1002/dmr.5610010404.

4. Ainsworth BE, Haskell WL, Herrmann SD, Meckes N, Bassett DR Jr, Tudor-Locke C, et al. 2011 Compendium of Physical Activities: a second update of codes and MET values. Med Sci Sports Exerc 2011; 43: 1575-1581, doi: 10.1249/MSS.0b013e31821ece12.

5. Goldstein DS. Catecholamines and stress. Endocr Regul 2003; 37: 69-80.

6. Pires W, Wanner SP, La Guardia RB, Rodrigues LO, Silveira SA, Coimbra CC, et al. Intracerebroventricular physostigmine enhances blood pressure and heat loss in running rats. J Physiol Pharmacol 2007; 58: 3-17.

7. Wanner SP, Guimaraes JB, Rodrigues LO, Marubayashi U, Coimbra CC, Lima NR. Muscarinic cholinoceptors in the ventromedial hypothalamic nucleus facilitate tail heat loss during physical exercise. Brain Res Bull 2007; 73: 28-33, doi: 10.1016/j.brainresbull.2007.03.004.

8. Rabelo PC, Almeida TF, Guimaraes JB, Barcellos LA, Cordeiro LM, Moraes MM, et al. Intrinsic exercise capacity is related to differential monoaminergic activity in the rat forebrain. Brain Res Bull 2015; 112: 7-13, doi: 10.1016/j.brainresbull.2015.01.006.

9. Primola-Gomes TN, Pires W, Rodrigues LO, Coimbra CC, Marubayashi U, Lima NR. Activation of the central cholinergic and immune responses. Some of these TRPV1-mediated effects have already been observed during exercise, such as increased energy expenditure and lipolysis rate and the modulation of the exercise pressor reflex. The TRPV1mediated modulation of several physiological responses is summarized in Figure 3.

This broad range of physiological functions controlled by the TRPV1 channel suggests that TRPV1 activation regulates physical (aerobic) performance. In addition, the data presented in this review indicate new possibilities for investigating the role of the TRPV1 channel in the acute effects induced by a bout of physical exercise and in the chronic effects induced by physical training.

\section{Acknowledgments}

A.S.R. Hudson was a recipient of a Master's fellowship from the Coordenação de Aperfeiçoamento de Pessoal de Nível Superior (CAPES). A.C. Kunstetter and W.C. Damasceno are recipients of PhD fellowships from CAPES. S.P. Wanner received a grant (\#473737/2013-2) from the Conselho Nacional de Desenvolvimento Científico e Tecnológico (CNPq) to investigate the association between thermoregulatory and inflammatory responses during physical exercise. pathway increases post-exercise tail heat loss in rats. Neurosci Lett 2007; 413: 1-5, doi: 10.1016/j.neulet.2006.10.042.

10. Lacerda AC, Marubayashi $\mathrm{U}$, Balthazar $\mathrm{CH}$, Leite $\mathrm{LH}$, Coimbra CC. Central nitric oxide inhibition modifies metabolic adjustments induced by exercise in rats. Neurosci Lett 2006; 410: 152-156, doi: 10.1016/j.neulet.2006.09.067.

11. Pires W, Wanner SP, Lima MR, Fonseca IA, Fumega U, Haibara AS, et al. Physical exercise performance in temperate and warm environments is decreased by an impaired arterial baroreflex. PLoS One 2013; 8: e72005, doi: 10.1371/journal.pone.0072005.

12. Lambert EV, St Clair GA, Noakes TD. Complex systems model of fatigue: integrative homoeostatic control of peripheral physiological systems during exercise in humans. $\mathrm{Br} J$ Sports Med 2005; 39: 52-62, doi: 10.1136/bjsm.2003.011247.

13. Marcora SM. Do we really need a central governor to explain brain regulation of exercise performance? Eur J Appl Physiol 2008; 104: 929-931, doi: 10.1007/s00421-008-0818-3.

14. Wang $\mathrm{H}$, Siemens J. TRP ion channels in thermosensation, thermoregulation and metabolism. Temperature 2015; 2: 178-187, doi: 10.1080/23328940.2015.1040604.

15. Caterina MJ. Transient receptor potential ion channels as participants in thermosensation and thermoregulation. $A m \mathrm{~J}$ Physiol Regul Integr Comp Physiol 2007; 292: R64-R76, doi: 10.1152/ajpregu.00446.2006.

16. Vriens $\mathrm{J}$, Nilius $\mathrm{B}$, Voets $\mathrm{T}$. Peripheral thermosensation in mammals. Nat Rev Neurosci 2014; 15: 573-589, doi: 10.1038/nrn3784.

17. Romanovsky AA, Almeida MC, Garami A, Steiner AA, Norman MH, Morrison SF, et al. The transient receptor 
potential vanilloid-1 channel in thermoregulation: a thermosensor it is not. Pharmacol Rev 2009; 61: 228-261, doi: 10.1124/pr.109.001263.

18. Hilton JK, Rath P, Helsell CV, Beckstein O, Van Horn WD. Understanding thermosensitive transient receptor potential channels as versatile polymodal cellular sensors. Biochemistry 2015; 54: 2401-2413, doi: 10.1021/acs.biochem.5b00071.

19. Caterina MJ, Schumacher MA, Tominaga M, Rosen TA, Levine JD, Julius D. The capsaicin receptor: a heatactivated ion channel in the pain pathway. Nature 1997; 389: 816-824, doi: 10.1038/39807.

20. Tominaga M, Caterina MJ, Malmberg AB, Rosen TA, Gilbert $\mathrm{H}$, Skinner K, et al. The cloned capsaicin receptor integrates multiple pain-producing stimuli. Neuron 1998; 21: 531-543, doi: 10.1016/S0896-6273(00)80564-4.

21. Caterina MJ, Leffler A, Malmberg AB, Martin WJ, Trafton J, Petersen-Zeitz KR, et al. Impaired nociception and pain sensation in mice lacking the capsaicin receptor. Science 2000; 288: 306-313, doi: 10.1126/science.288.5464.306.

22. Nelson E. The constitution of capsaicin, the pungent principal of capsicum. J Am Chem Soc 1919; 41: 11151121, doi: 10.1021/ja02228a011.

23. Caterina MJ, Julius $D$. The vanilloid receptor: a molecular gateway to the pain pathway. Annu Rev Neurosci 2001; 24: 487-517, doi: 10.1146/annurev.neuro.24.1.487.

24. Szallasi A, Nilsson S, Farkas-Szallasi T, Blumberg PM, Hokfelt T, Lundberg JM. Vanilloid (capsaicin) receptors in the rat: distribution in the brain, regional differences in the spinal cord, axonal transport to the periphery, and depletion by systemic vanilloid treatment. Brain Res 1995; 703: 175-183, doi: 10.1016/0006-8993(95)01094-7.

25. Peles S, Medda BK, Zhang Z, Banerjee B, Lehmann A, Shaker $R$, et al. Differential effects of transient receptor vanilloid one (TRPV1) antagonists in acid-induced excitation of esophageal vagal afferent fibers of rats. Neuroscience 2009; 161: 515-525, doi: 10.1016/j.neuroscience.2009.03.040.

26. Hori T, Shinohara K. Hypothalamic thermo-responsive neurones in the new-born rat. J Physiol 1979; 294: 541560, doi: 10.1113/jphysiol.1979.sp012945.

27. Lotteau S, Ducreux S, Romestaing C, Legrand C, Van Coppenolle F. Characterization of functional TRPV1 channels in the sarcoplasmic reticulum of mouse skeletal muscle. PLoS One 2013; 8: e58673, doi: 10.1371/journal.pone.0058673.

28. Holzer P. Transient receptor potential (TRP) channels as drug targets for diseases of the digestive system. Pharmacol Ther 2011; 131: 142-170, doi: 10.1016/j.pharmthera.2011.03.006.

29. Toth A, Czikora A, Pasztor ET, Dienes B, Bai P, Csernoch L, et al. Vanilloid receptor-1 (TRPV1) expression and function in the vasculature of the rat. $J$ Histochem Cytochem 2014; 62: 129-144, doi: 10.1369/0022155413513589.

30. Sun H, Li DP, Chen SR, Hittelman WN, Pan HL. Sensing of blood pressure increase by transient receptor potential vanilloid 1 receptors on baroreceptors. J Pharmacol Exp Ther 2009; 331: 851-859, doi: 10.1124/jpet.109.160473.

31. Garami A, Pakai E, Oliveira DL, Steiner AA, Wanner SP, Almeida $M C$, et al. Thermoregulatory phenotype of the Trpv1 knockout mouse: thermoeffector dysbalance with hyperkinesis. J Neurosci 2011; 31: 1721-1733, doi: 10.1523/JNEUROSCI.4671-10.2011.

32. Wanner SP, Garami A, Romanovsky AA. Hyperactive when young, hypoactive and overweight when aged: connecting the dots in the story about locomotor activity, body mass, and aging in Trpv1 knockout mice. Aging 2011; 3: 450-454, doi: 10.18632/aging.100306.

33. Yu SQ, Wang DH. Enhanced salt sensitivity following shRNA silencing of neuronal TRPV1 in rat spinal cord. Acta Pharmacol Sin 2011; 32: 845-852, doi: 10.1038/aps.2011.43.

34. Luo Z, Ma L, Zhao Z, He H, Yang D, Feng X, et al. TRPV1 activation improves exercise endurance and energy metabolism through PGC-1alpha upregulation in mice. Cell Res 2012; 22: 551-564, doi: 10.1038/cr.2011.205.

35. Melton DW. The use of gene targeting to develop animal models for human genetic diseases. Biochem Soc Trans 1990; 18: 1035-1039, doi: 10.1042/bst0181035.

36. Snitker S, Fujishima Y, Shen H, Ott S, Pi-Sunyer X, Furuhata $Y$, et al. Effects of novel capsinoid treatment on fatness and energy metabolism in humans: possible pharmacogenetic implications. Am J Clin Nutr 2009; 89: 45-50, doi: 10.3945/ ajcn.2008.26561.

37. Haramizu S, Kawabata F, Ohnuki K, Inoue N, Watanabe T, Yazawa S, et al. Capsiate, a non-pungent capsaicin analog, reduces body fat without weight rebound like swimming exercise in mice. Biomed Res 2011; 32: 279-284, doi: 10.2220/biomedres.32.279.

38. Bloomer RJ, Canale RE, Shastri S, Suvarnapathki S. Effect of oral intake of capsaicinoid beadlets on catecholamine secretion and blood markers of lipolysis in healthy adults: a randomized, placebo controlled, double-blind, cross-over study. Lipids Health Dis 2010; 9: 72, doi: 10.1186/1476-511X-9-72.

39. Yamashita H, Wang Z, Wang Y, Furuyama T, Kontani Y, Sato $Y$, et al. Impaired basal thermal homeostasis in rats lacking capsaicin-sensitive peripheral small sensory neurons. $J$ Biochem 2008; 143: 385-393, doi: 10.1093/jb/mvm233.

40. Caspersen CJ, Powell KE, Christenson GM. Physical activity, exercise, and physical fitness: definitions and distinctions for health-related research. Public Health Rep 1985; 100: 126-131.

41. Davis JB, Gray J, Gunthorpe MJ, Hatcher JP, Davey PT, Overend $P$, et al. Vanilloid receptor- 1 is essential for inflammatory thermal hyperalgesia. Nature 2000; 405: 183-187, doi: 10.1038/35012076.

42. Di Marzo V, Lastres-Becker I, Bisogno T, De Petrocellis L, Milone A, Davis JB, et al. Hypolocomotor effects in rats of capsaicin and two long chain capsaicin homologues. Eur $J$ Pharmacol 2001; 420: 123-131, doi: 10.1016/S0014-2999 (01)01012-3.

43. Proulx K, Cota D, Castaneda TR, Tschop MH, D'Alessio DA, Tso $P$, et al. Mechanisms of oleoylethanolamide-induced changes in feeding behavior and motor activity. $A m \mathrm{~J}$ Physiol Regul Integr Comp Physiol 2005; 289: R729-R737, doi: 10.1152/ajpregu.00029.2005.

44. Wiley JL, Razdan RK, Martin BR. Evaluation of the role of the arachidonic acid cascade in anandamide's in vivo effects in mice. Life Sci 2006; 80: 24-35, doi: 10.1016/j. Ifs.2006.08.017.

45. Wise LE, Shelton CC, Cravatt BF, Martin BR, Lichtman AH. Assessment of anandamide's pharmacological effects in mice deficient of both fatty acid amide hydrolase and cannabinoid CB1 receptors. Eur J Pharmacol 2007; 557: 44-48, doi: 10.1016/j.ejphar.2006.11.002.

46. Alawi KM, Aubdool AA, Liang L, Wilde E, Vepa A, Psefteli $M P$, et al. The sympathetic nervous system is controlled by 
transient receptor potential vanilloid 1 in the regulation of body temperature. FASEB $J$ 2015; 29: 4285-4298, doi: 10.1096/fj.15-272526.

47. Steiner AA, Turek VF, Almeida MC, Burmeister JJ, Oliveira $\mathrm{DL}$, Roberts $\mathrm{JL}$, et al. Nonthermal activation of transient receptor potential vanilloid-1 channels in abdominal viscera tonically inhibits autonomic cold-defense effectors. J Neurosci 2007; 27: 7459-7468, doi: 10.1523/JNEUROSCI.1483-07.2007.

48. Smith SA, Leal AK, Williams MA, Murphy MN, Mitchell JH, Garry MG. The TRPv1 receptor is a mediator of the exercise pressor reflex in rats. J Physiol 2010; 588: 1179-1189, doi: 10.1113/jphysiol.2009.184952.

49. Banvolgyi A, Palinkas L, Berki T, Clark N, Grant AD, Helyes $Z$, et al. Evidence for a novel protective role of the vanilloid TRPV1 receptor in a cutaneous contact allergic dermatitis model. J Neuroimmunol 2005; 169: 86-96, doi: 10.1016/j. jneuroim.2005.08.012.

50. Kim KM, Kawada T, Ishihara K, Inoue K, Fushiki T. Increase in swimming endurance capacity of mice by capsaicininduced adrenal catecholamine secretion. Biosci Biotechnol Biochem 1997; 61: 1718-1723, doi: 10.1271/bbb.61.1718.

51. Oh TW, Oh TW, Ohta F. Dose-dependent effect of capsaicin on endurance capacity in rats. Br J Nutr 2003; 90: 515-520, doi: 10.1079/BJN2003919

52. Dousset E, Marqueste T, Decherchi P, Jammes $Y$, Grelot L. Effects of neonatal capsaicin deafferentation on neuromuscular adjustments, performance, and afferent activities from adult tibialis anterior muscle during exercise. $J$ Neurosci Res 2004; 76: 734-741, doi: 10.1002/jnr.20110.

53. Trudeau F, Milot M. Capsaicin-sensitive nerves and endurance exercise in the rat. Physiol Behav 1996; 59: 355-359, doi: 10.1016/0031-9384(95)02106-X.

54. Jancsó-Gábor A, Szolcsanyi J, Jancsó N. Stimulation and desensitization of the hypothalamic heat-sensitive structures by capsaicin in rats. J Physiol 1970; 208: 449-459, doi: 10.1113/jphysiol.1970.sp009130.

55. Almeida MC, Steiner AA, Branco LG, Romanovsky AA. Cold-seeking behavior as a thermoregulatory strategy in systemic inflammation. Eur J Neurosci 2006; 23: 33593367, doi: 10.1111/j.1460-9568.2006.04854.x.

56. Donnerer J, Lembeck F. Heat loss reaction to capsaicin through a peripheral site of action. Br J Pharmacol 1983; 79: 719-723, doi: 10.1111/j.1476-5381.1983.tb10009.x.

57. Jancsó-Gábor A, Szolcsanyi J, Jancsó N. Irreversible impairment of thermoregulation induced by capsaicin and similar pungent substances in rats and guinea-pigs. J Physiol 1970; 206: 495-507, doi: 10.1113/jphysiol.1970.sp009027.

58. Straub RH. TRPV1, TRPA1, and TRPM8 channels in inflammation, energy redirection, and water retention: role in chronic inflammatory diseases with an evolutionary perspective. $\mathrm{J} \mathrm{Mol}$ Med 2014; 92: 925-937, doi: 10.1007/s00109-014-1175-9.

59. Voight EA, Gomtsyan AR, Daanen JF, Perner RJ, Schmidt RG, Bayburt EK, et al. Discovery of (R)-1-(7-chloro-2,2-bis (fluoromethyl)chroman-4-yl)-3-(3-methylisoquinolin-5-yl)urea (A-1165442): a temperature-neutral transient receptor potential vanilloid-1 (TRPV1) antagonist with analgesic efficacy. J Med Chem 2014; 57: 7412-7424, doi: 10.1021/jm500916t.

60. Garami A, Shimansky YP, Pakai E, Oliveira DL, Gavva NR, Romanovsky AA. Contributions of different modes of TRPV1 activation to TRPV1 antagonist-induced hyperthermia.
J Neurosci 2010; 30: 1435-1440, doi: 10.1523/JNEUROSCI.5150-09.2010.

61. Spicarova D, Palecek J. The role of spinal cord vanilloid (TRPV1) receptors in pain modulation. Physiol Res 2008; 57 (Suppl 3): S69-S77.

62. Gavva NR, Treanor JJ, Garami A, Fang L, Surapaneni S, Akrami $A$, et al. Pharmacological blockade of the vanilloid receptor TRPV1 elicits marked hyperthermia in humans. Pain 2008; 136: 202-210, doi: 10.1016/j.pain.2008.01.024.

63. Gavva NR, Bannon AW, Surapaneni S, Hovland DN Jr, Lehto SG, Gore A, et al. The vanilloid receptor TRPV1 is tonically activated in vivo and involved in body temperature regulation. J Neurosci 2007; 27: 3366-3374, doi: 10.1523/ JNEUROSCI.4833-06.2007.

64. Obál F Jr, Jancsó G, Hajós M, Obál F. Differences in the mechanisms of the thermoregulatory impairment induced by capsaicin in newborn and adult rats. Acta Physiol Hung 1987; 69: 437-445.

65. Dib B. Dissociation between peripheral and central heat loss mechanisms induced by neonatal capsaicin. Behav Neurosci 1983; 97: 822-825, doi: 10.1037/0735-7044.97.5.822.

66. Kentish SJ, Frisby CL, Kritas S, Li H, Hatzinikolas G, O'Donnell TA, et al. TRPV1 Channels and Gastric Vagal Afferent Signalling in Lean and High Fat Diet Induced Obese Mice. PLoS One 2015; 10: e0135892, doi: 10.1371/journal. pone. 0135892 .

67. Shin KO, Moritani T. Alterations of autonomic nervous activity and energy metabolism by capsaicin ingestion during aerobic exercise in healthy men. J Nutr Sci Vitaminol 2007; 53: 124-132, doi: 10.3177/jnsv.53.124.

68. Yang D, Luo Z, Ma S, Wong WT, Ma L, Zhong J, et al. Activation of TRPV1 by dietary capsaicin improves endothelium-dependent vasorelaxation and prevents hypertension. Cell Metab 2010; 12: 130-141, doi: 10.1016/j.cmet.2010. 05.015 .

69. Ching LC, Kou YR, Shyue SK, Su KH, Wei J, Cheng LC, et al. Molecular mechanisms of activation of endothelial nitric oxide synthase mediated by transient receptor potential vanilloid type 1. Cardiovasc Res 2011; 91: 492501, doi: $10.1093 / \mathrm{cvr} / \mathrm{cvr} 104$.

70. Tamaki C, Nawa H, Takatori S, Oda S, Sendo T, Zamami Y, et al. Anandamide induces endothelium-dependent vasoconstriction and CGRPergic nerve-mediated vasodilatation in the rat mesenteric vascular bed. J Pharmacol Sci 2012; 118: 496-505, doi: 10.1254/jphs.11236FP.

71. Wang HJ, Li YL, Zucker IH, Wang W. Exercise training prevents skeletal muscle afferent sensitization in rats with chronic heart failure. Am J Physiol Regul Integr Comp Physiol 2012; 302: R1260-R1270, doi: 10.1152/ajpregu.00054.2012.

72. Brouns $F$, Beckers $E$. Is the gut an athletic organ? Digestion, absorption and exercise. Sports Med 1993; 15: 242-257, doi: 10.2165/00007256-199315040-00003.

73. Jeukendrup AE, Vet-Joop K, Sturk A, Stegen JH, Senden J, Saris $\mathrm{WH}$, et al. Relationship between gastro-intestinal complaints and endotoxaemia, cytokine release and the acute-phase reaction during and after a long-distance triathlon in highly trained men. Clin Sci 2000; 98: 47-55, doi: $10.1042 / \operatorname{cs} 0980047$.

74. Costa KA, Soares AD, Wanner SP, Santos R, Fernandes SO, Martins FS, et al. L-arginine supplementation prevents increases in intestinal permeability and bacterial 
translocation in male Swiss mice subjected to physical exercise under environmental heat stress. J Nutr 2014; 144: 218-223, doi: 10.3945/jn.113.183186.

75. Kato S, Aihara E, Nakamura A, Xin H, Matsui H, Kohama K, et al. Expression of vanilloid receptors in rat gastric epithelial cells: role in cellular protection. Biochem Pharmacol 2003; 66: 1115-1121, doi: 10.1016/S0006-2952(03)00461-1.

76. Ma J, Harnett KM, Behar J, Biancani P, Cao W. Signaling in TRPV1-induced platelet activating factor (PAF) in human esophageal epithelial cells. Am J Physiol Gastrointest Liver Physiol 2010; 298: G233-G240, doi: 10.1152/ajpgi.00409.2009.

77. Wanner SP, Garami A, Pakai E, Oliveira DL, Gavva NR, Coimbra $\mathrm{CC}$, et al. Aging reverses the role of the transient receptor potential vanilloid-1 channel in systemic inflammation from anti-inflammatory to proinflammatory. Cell Cycle 2012; 11: 343-349, doi: 10.4161/cc.11.2.18772.

78. Holzer P. TRPV1 and the gut: from a tasty receptor for a painful vanilloid to a key player in hyperalgesia. Eur J Pharmacol 2004; 500: 231-241, doi: 10.1016/j.ejphar.2004.07.028.

79. Rajasekaran SA, Beyenbach KW, Rajasekaran AK. Interactions of tight junctions with membrane channels and transporters. Biochim Biophys Acta 2008; 1778: 757-769, doi: 10.1016/j.bbamem.2007.11.007.

80. Guptill V, Cui X, Khaibullina A, Keller JM, Spornick N, Mannes A, et al. Disruption of the transient receptor potential vanilloid 1 can affect survival, bacterial clearance, and cytokine gene expression during murine sepsis. Anesthesiology 2011; 114: 1190-1199, doi: 10.1097/ALN.0b013e318212515b.

81. Wang $Y$, Novotny M, Quaiserova-Mocko V, Swain GM, Wang DH. TRPV1-mediated protection against endotoxininduced hypotension and mortality in rats. Am J Physiol
Regul Integr Comp Physiol 2008; 294: R1517-R1523, doi: 10.1152/ajpregu.00005.2008.

82. Bradford CD, Cotter JD, Thorburn MS, Walker RJ, Gerrard DF. Exercise can be pyrogenic in humans. Am J Physiol Regul Integr Comp Physiol 2007; 292: R143-R149, doi: 10.1152/ajpregu.00926.2005.

83. Rummel C, Sachot C, Poole S, Luheshi GN. Circulating interleukin-6 induces fever through a STAT3-linked activation of COX-2 in the brain. Am J Physiol Regul Integr Comp Physiol 2006; 291: R1316-R1326, doi: 10.1152/ajpregu.00301.2006.

84. Fortes MB, Di Felice U, Dolci A, Junglee NA, Crockford MJ, West $\mathrm{L}$, et al. Muscle-damaging exercise increases heat strain during subsequent exercise heat stress. Med Sci Sports Exerc 2013; 45: 1915-1924, doi: 10.1249/MSS.0b013e318294b0f8.

85. Ciura S, Bourque CW. Transient receptor potential vanilloid 1 is required for intrinsic osmoreception in organum vasculosum lamina terminalis neurons and for normal thirst responses to systemic hyperosmolality. J Neurosci 2006; 26 : 9069-9075, doi: 10.1523/JNEUROSCI.0877-06.2006.

86. Cavuoto P, McAinch AJ, Hatzinikolas G, Janovska A, Game P, Wittert GA. The expression of receptors for endocannabinoids in human and rodent skeletal muscle. Biochem Biophys Res Commun 2007; 364: 105-110, doi: 10.1016/j.bbrc.2007.09.099.

87. Xin $H$, Tanaka $H$, Yamaguchi $M$, Takemori $S$, Nakamura $A$, Kohama K. Vanilloid receptor expressed in the sarcoplasmic reticulum of rat skeletal muscle. Biochem Biophys Res Commun 2005; 332: 756-762, doi: 10.1016/j.bbrc.2005.05.016.

88. Ito N, Ruegg UT, Kudo A, Miyagoe-Suzuki Y, Takeda S. Activation of calcium signaling through Trpv1 by nNOS and peroxynitrite as a key trigger of skeletal muscle hypertrophy. Nat Med 2013; 19: 101-106, doi: 10.1038/nm.3019. 